\title{
Why Kosovo?
}

\author{
Glen Segell
}

\begin{abstract}
The quest for European Security involves the protracted interaction of international diplomacy, war and domestic politics. This article shows how Kosovo is an interplay of all these components. Kosovo is a case in which NATO believes that it is strengthening its position and collective security by solidifying the recent Enlargement Process to attain Collective Security-diplomatically, organizationally and through the Military of CJTF. The price is over one million displaced persons (refugees), and the risk of endangering European Security through the failure of the European Disarmament process as indicated by the failure of the Russian Duma eoen to debate START II/III
\end{abstract}

\section{Résumé}

La recherche d'une sécurité européenne implique l' interactiond long terme de la diplomatie internationale, de la guerre, et des politiques domestiques. Le présent article mon tre comment le Kosovo est un point nodal, où ces différents eléments sont en contact. Le Kosovo est un cas de figure dans lequel l'OTAN croit renforcer sa position et la sécurité collective en solidifiant le récent Enlargement Process to attain Collective Security, et ce, diplomatiquement, organi-sationnellement, et via les structures militaires $d u$ CJTF. Le prixà payer est alors le suivant: plus d'un million de personnes déplacées (réfugiés), et une menace certaine sur la sécurité européenne par la faillite $d u$ processus de désarmement européen, patente et manifestedansl'in-

Dr. Glen Segell, Lord of Deadington, is the Director of the London-based Institute of Security Policy. His preoious institutional affiliations include the Centre for Defence Studies and Department of War Studies at King's College University of London and the Untocrsity of Reading where he taught courses on Strategic Studies. Dr. Segell is the author of 17 books and over 40 articles. capacité de la Douma russed simplement entamer le débat sur les accords START II et III.

The choice by NATO to undertake military action in Kosovo is unique, in singling out one specific humanitarian crisis in which to intervene apparently without careful thought about the consequences-specifically, the ramification of refugees.

The situation in former Yugoslavia, as in almost all International crises, generates humanitarian problems and some form of refugee consequence. NATOaction in Kosovohas aggravated the refugee problem there to the extent that one can say there is no longer a refugee or ethnicproblem in Kosovo-it is now in the neighbouring states of the European Union, who have to deal with, according toestimates, over onemillion displaced persons. Vague references to the return of these persons to their homes before winter can hardly be believed!

It all started when the United States and its allies geared up for military strikes on October 11, 1998 against Serbian targets as a reaction to the "mass graves incidents" in Kosovo of September 1998. Such incidents were not new, but came at a time when NATO was trying to unify after its recent expansion to include Poland, the Czech State and Hungary, while also attempting to find ameans to test the Strategy of Combined and Joint Task Forces (CJTF). Kosovo appeared to offer a relatively easy and low riskmilitary and political means of trying outboth the expanded organization and CJTF. NATO had no other interest in Kosovo-thehumanitarian crises was a "casus belli" that could have been ignored, as it has been for years in Kosovo and other regions of the former Yugoslavia.

However, from the onset, the possible ramifications of refugees and the use of ground forces were not considered. No plans were made to airlift troops in, or to prepare for a mass refugee problem. It was to be an air campaign similar to the oneconducted a few months previously against Iraq! The main military activity would be conducted by the United States. Other NATO members would supply token military forces and would support the action through political consensus in NATO organizational meetings in the comfort of board rooms in Brussels.

The Kosovar action was therefore aimed at one (and only one) goal of European Security: keeping the new and old members of NATO unified. No-one even thought of listening to Russia or considered other aspects of European Security, such as the process of disarmament.

Had anyone listened, they would have heard Pavel Felgenhauer, defense and security editor for the newspaper Segodnya, stating about NATO action that "Communists and nationalists will cry out that Mother Russia is next in line for attack and many Russians, stunned by the collapse of their Western-oriented quasi-market economy, will believe them."1 They also would have been able to learn about ethnic problems and refugees from Russia's failed military action in Chechnya.

This was not rhetoric, for reports show that Russian military and political leaders were threatening to sever ties with NATO; to send peacekeeping troops to the Yugoslav Federation to prevent a NATO attack; to unilaterally end an arms embargo against the Yugoslav Federation; and to further stall nuclear arms reduction agreements with the United States.

The initiative for such activities came from the State Duma, the lower house of the Russian parliament, which has on a number of occasions threatened to break ties with NATO. Ultranationalist groups like the Union of Officers are signing up volunteers to fight for Ser- 
bia. ${ }^{2}$ This is all disturbing, but nothing the West has not heard about beforeand so it was ignored by NATO planners.

In October 1998, the sabre-rattling was accompanied by a round of telephone calls to Western leaders by President Boris N. Yeltsin and Prime Minister Yevgeny Primakov, as well as some urgent shuttle diplomacy by Foreign Minister Igor Ivanov. Russia expressed its objection to the violent methods used by Milosevic to crack down on separatist Kosovo, but stated that the conflict should be settled through talks and vowed to use its power of veto to halt any UN Security Council resolution on the use of force against Serbia. $^{3}$

Ivanov met with Milosevic in Belgrade, then flew to London to present his counterparts from the United States, Britain, France, Germany, and Italywhich, together with Russia, make up the Contact Group on Yugoslaviawith a proposal from the Yugoslav leader to unconditionally allow European officials into Kosovo to monitor Serb troop withdrawal. Had this been heard and adhered to then, there would not have been the refugee problem that exists today.

The danger of the military approach taken by NATO, Russian officials and analysts say, is the precedent it sets for future conflict-solving in Europe. "Carried out with or without a United Nations mandate, proposed NATO air strikes against Serbia would inevitably create a controversial precedent for the post-Cold War world," Vladimir Lukin, head of the foreign relations committee in the lower house of parliament, the State Duma, said.

If a regional organization like NATO ... without a decision by the UN ... decides to launch a military strike against a country that is solving its ethnic problems in a way we don't like ... that means for Russia that next time, the same thing can happen when someone does not like the way we are conducting affairs. ${ }^{4}$

Russia's parliament also declared that any NATO military action over Kosovo taken without UN approval would be considered an "illegal act of aggression." In a unanimous resolution, the State Duma said it would review all agreements between NATO and Russia if the Western alliance were to opt for the use of force against Yugoslavia. Such a decision "may cause irreparable harm to the international security system fixed in the UN Charter," the resolution stated.

The Communist leader of the State Duma (Russia's lower house of parliament) speaker Gennady Seleznyov, warned that "if a single bomb or rocket is dropped in Serbia, the Yugoslav army will retaliate ... and this can trigger a fullscale war." He also stressed that if the United States initiates military action, U.S. officials "may say goodbye to ratification of the START II treaty," and added, "We were moving toward ratifying it. IfNA TO inflicts this blow against Kosovo, it will all be thrown back. It will all be forgotten.,,6

Itwas not immediately clear whether Seleznyov had coordinated his comments with Yeltsin or with Russian Prime Minister Yevgeny Primakov, both of whom favour ratification of START II but oppose military action against $\mathrm{Yu}$ goslavia.

An explanation offered for such terse statements is the nature of Russian domestic politics. Russia already has a province, Chechnya, that won de facto independence after Moscow's twentymonth campaign failed to crush a separatist rebellion. Ethnic tensions are strong in Chechnya's neighbouring province, Dagestan, and separatist moods run high in the Volga region of Tatarstan. U.S. specialists say Russia is less worried about the precedent that NATO intervention would set for Chechnya or Tatarstan, than it is by the idea that the West can do whatever it chooses in Moscow's backyard. "The main reason the Russians oppose [NATO strikes] is psychological," said Kurt Bassuener, director of the Balkan Action Council in Washington. "They don't want to be seen as being an adjunctto the West. It's a cost-free way for Russia to differentiate itself."7

Months into the military action against Kosovo, some of these warnings

have come true: Russia is still stalling with the Disarmament Process-Europe is no further advanced in attaining security than it was prior to military action in Kosovo. Furthermore, Europe is now facing a refugee crisis-the largest since the end of World War II.

The lesson of the Cold War is clear for of today' s Cold Diplomacy-Do not ignore the obvious! For NATO, this means that it is now involved in a protracted military air campaign against a country which does not even have an Embassy in Washington, O.C. It means that the Disarmament process of START II/III and beyond has been set back indefinitely, and that the economic and social structures of the European Union are facing the arduous task of dealing with a mass refugee crisis. Have the goals of NATO action been achieved-NATO enlargement unification and CJTF? The answer is NO-the new NATO members have not contributed any air forces, and so far the only forces used have been air power; hence, the CJTF has yet to be tested. Even if NATO proves to be successful in CJTF and in its enlargement, the costs remain-including that of over one million displaced persons! ••

\section{Notes}

1. FBIS: Segodnya, 11 October 1998, Page 3, Col. 4-5.

2. Literaturnaya Gazeta, Moscow, Vol. 3 , No. 1 Page 25, September 1998.

3. Izvestia, Vol. 22, No.1, Front Page, 1 November 1998.

4. The Times, 5 November 1998, Page 7, Col. 2.

5. BBC: World-Service Reporting: 2 March 1999:14:00 GMT News.

6. BBC: World-Service Reporting: 2 March 1999:14:00 GMT News.

7. Balkan Action Council Washington: Balkan Watch: 3 November 1998. cl

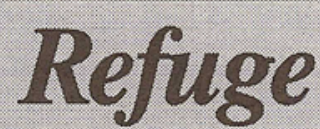

Canada's Periodical on Refugees

Available from: Centre for Refugee Studies

Refuge, Vol. 18, No.3 (August 1999)

C Glen Segell, 1999. This open-access work is licensed under a Creative Commons Attribution-NonCommercial 4.0 International 